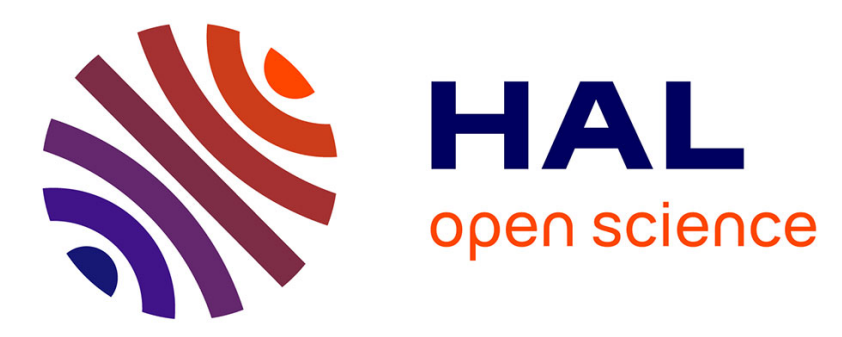

\title{
Inhibition of P-glycoprotein-mediated multidrug efflux by aminomethylene and ketomethylene analogs of reversins
}

\author{
Ali Koubeissi, Imad Raad, Laurent Ettouati, David Guilet, Charles \\ Dumontet, Joëlle Paris
}

\section{To cite this version:}

Ali Koubeissi, Imad Raad, Laurent Ettouati, David Guilet, Charles Dumontet, et al.. Inhibition of P-glycoprotein-mediated multidrug efflux by aminomethylene and ketomethylene analogs of reversins. Bioorganic and Medicinal Chemistry Letters, 2006, 16 (21), pp.5700 - 5703. 10.1016/j.bmcl.2006.07.059 . hal-01653673

\section{HAL Id: hal-01653673 \\ https://hal.science/hal-01653673}

Submitted on 15 Feb 2018

HAL is a multi-disciplinary open access archive for the deposit and dissemination of scientific research documents, whether they are published or not. The documents may come from teaching and research institutions in France or abroad, or from public or private research centers.
L'archive ouverte pluridisciplinaire HAL, est destinée au dépôt et à la diffusion de documents scientifiques de niveau recherche, publiés ou non, émanant des établissements d'enseignement et de recherche français ou étrangers, des laboratoires publics ou privés. 


\title{
Inhibition of P-glycoprotein-mediated multidrug efflux by aminomethylene and ketomethylene analogs of reversins
}

\author{
Ali Koubeissi, ${ }^{\mathrm{a}}$ Imad Raad, ${ }^{\mathrm{a}}$ Laurent Ettouati, ${ }^{\mathrm{a}}$ David Guilet, ${ }^{\mathrm{a}}$ Charles Dumontet ${ }^{\mathrm{b}}$ and \\ Joelle Paris ${ }^{\mathrm{a}^{*}}$ \\ ${ }^{a}$ Université Claude Bernard Lyon 1, Institut des Sciences Pharmaceutiques et Biologiques, EA 3741 Écosystèmes et \\ Molécules bioactives, 69373 Lyon cedex 08, France \\ ${ }^{b}$ Université Claude Bernard Lyon 1, Faculté de Médecine, Laboratoire de Cytologie analytique, INSERM U590, 69373 \\ Lyon cedex 08, France
}

This is where the receipt/accepted dates will go; Received Month XX, 2000; Accepted Month XX, 2000 [BMCL RECEIPT]

\begin{abstract}
Several aminomethylene analogs and a ketomethylene analog of reversins were synthesized in order to evaluate their ability to inhibit P-glycoprotein-mediated drug efflux in K562/R7 human leukemic cells overexpressing P-glycoprotein. These analogs retained good activity compared to cyclosporin A and the original reversins. (C2000 Elsevier Science Ltd. All rights reserved.
\end{abstract}

\begin{abstract}
Multidrug resistance (MDR) to anticancer agents remains a major cause of treatment failure in cancer chemotherapy. MDR describes the cross-resistance of tumor cell lines to several structurally unrelated chemotherapeutic agents after exposure to a single cytotoxic drug. This phenomenom is often associated with overexpression of several proteins. ${ }^{1}$ Among them P-glycoprotein (Pgp) is the most important one that belongs to the $\mathrm{ABC}$ superfamily of transporters which acts as a drug efflux pump. ${ }^{2,3}$
\end{abstract}

Numerous molecules have shown some activity on Pgp. ${ }^{4}$ Among them short linear hydrophobic peptides were described as chemosensitizers. ${ }^{5 a}$ Seprõdi and coll. showed that small hydrophobic peptide derivatives modulate Pgp-ATPase activity and inhibited the drug extrusion function of Pgp. ${ }^{5 b, c}$ These compounds are a family of di- and tripeptide derivatives sharing some common physico-chemical and structural features. Some of them are dimerized aminoacids by diacid derivatives. The enhanced affinity to Pgp of these chemosensitizers finally coined reversins is ascribed to the hydrophobic nature of the side chains protected with bulky aromatic or alkyl groups. ${ }^{6}$ Among them reversin
121 1a showed the highest affinity and specificity for Pgp.<smiles>[Y7]CCCCNC(=O)C(CCC(=O)O[R7])NC(=O)OCc1ccccc1</smiles>

$$
\begin{aligned}
& \text { 1a } n=1, R^{1}=B n \\
& 1 \mathbf{b} n=2, R^{1}=D m p \\
& 1 c n=2, R^{1}=c H e x
\end{aligned}
$$

At $1-2 \mu \mathrm{M}$ this reversin was more effective than cyclosporin A for blocking colchicine transport in isolated membranes and reconstituted systems. In order to improve proteolytic stability and bioavailability of reversins we planned to synthesize aminomethylene and ketomethylene analogs of typical reversin representatives. We chose reversin $121 \mathbf{1 a}$ as our working model for dipeptide-type reversins and reversin 213 2a as a dimerized aminoacid containing succinyl unit. The reduced analogs $\mathbf{3 a - b}$ were synthesized using the classical reductive amination 


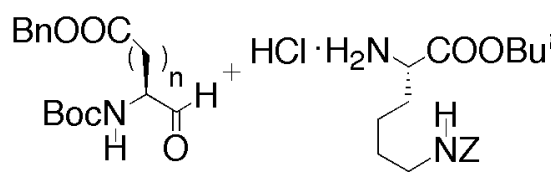

$$
n=1-2
$$



$3 \mathbf{a} n=1$

$3 b \mathrm{~b}=2$

Scheme 1. Reagents and conditions: (a) $\mathrm{NaBH}_{3} \mathrm{CN}, \mathrm{MeOH}, \mathrm{AcOH}, \mathrm{rt} 1 \mathrm{~h}, 52 \%(\mathrm{n}=1)$ and $57 \%(\mathrm{n}=2)$.

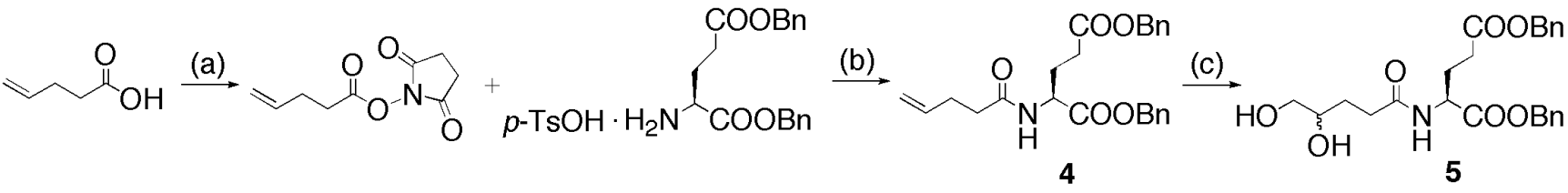<smiles>C=CC1CC(O)N(C(CCC(=O)OCc2ccccc2)C(=O)OCc2ccccc2)C1OCC(=O)OCCC(=O)NC(CCC(=O)OCc1ccccc1)C(=O)OCc1ccccc1</smiles><smiles>NC(C(=O)O[Ga])C(=O)O[Ga]</smiles>

$7 \mathrm{an}=1, \mathrm{R}^{1}=\mathrm{Bn}$

$7 \mathrm{~b} n=2, \mathrm{R}^{1}=\mathrm{Bn}$

$7 \mathrm{c} n=2, \mathrm{R}^{1}=\mathrm{Dmp}$

$7 \mathrm{~d} \mathrm{n}=2, \mathrm{R}^{1}=\mathrm{cHex}$

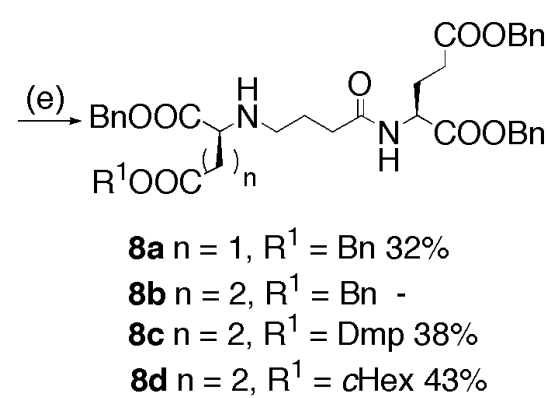

Scheme 2. Reagents and conditions: (a) $N$-Hydroxysuccinimide, DMAP, DCC, THF, $0^{\circ} \mathrm{C} 10$ min then rt 48 h, $94 \%$; (b) DIEA, DMF, rt 24 h, quant yield; (c) $\mathrm{OsO}_{4} 2.5 \%$ in $t$ - $\mathrm{BuOH}, \mathrm{NMO}$, THF, $\mathrm{H}_{2} \mathrm{O}$, rt $24 \mathrm{~h}, 86 \%$; (d) $\mathrm{NaIO}_{4}, \mathrm{THF}, \mathrm{H}_{2} \mathrm{O}, 3$ h, quant yield; (e) $\mathrm{NaBH}_{3} \mathrm{CN}, \mathrm{MeOH}, \mathrm{AcOH}, \mathrm{rt} 1-2 \mathrm{~h}$.<smiles>O=C(O)CCC(NC(=O)CCC(=O)NC(CCC(=O)OCc1ccccc1)C(=O)OCc1ccccc1)OCc1ccccc1</smiles>

$$
\begin{aligned}
& \mathbf{2} \mathbf{a} R^{1}=\mathrm{Bn} \\
& \mathbf{2} \mathbf{b} \mathrm{R}^{1}=c \text { Hex }
\end{aligned}
$$

strategy $^{7}$ starting from chiral pool derived aminoaldehydes according to Scheme $1 .{ }^{8}$

As far as reduced analogs of reversin 213 2a were concerned we started from 4-pentenoic acid which was activated as succinimidyl ester and then coupled to Lglutamic acid dibenzyl ester tosylate salt to obtain the amide 4 (Scheme 2). The corresponding aldehyde 6 was obtained by a two-step reaction with osmium tetroxide/4-methylmorpholine $\mathrm{N}$-oxide ${ }^{9}$ followed by oxidative cleavage of the diol $\mathbf{5}$ with sodium periodate. It is noteworthy that aldehyde $\mathbf{6}$ exists in equilibrium with the corresponding hemiaminals $\mathbf{6}^{\prime}$ ' as previously described in similar reactions. ${ }^{10 a, b}$ Structure of the diastereoisomeric hemiaminals 6' was assessed by ESIMS and HSQC and HMBC experiments. ${ }^{10 \mathrm{c}}$ The last step consisted in obtaining the reduced analogs 8a-d of reversin 213 2a. However in the standard reductive amination conditions, the reaction between diprotected L-glutamic acid $\mathbf{7 b}$ and aldehyde $\mathbf{6}$ did not afford the corresponding secondary amine $\mathbf{8 b}$ but instead the pyrrolidinone 9 in 38\% yield (Figure 1). This result is explained by nucleophilic attack of the generated secondary amine on the adjacent benzyl ester side chain as observed for similar derivatives. ${ }^{11}$ So as to avoid cyclization several protected derivatives of L-glutamic acid such as the 2,4-dimethyl-3-pentyl ${ }^{\text {Ra }}$ and cyclohexyl $^{12 b}$ esters known to prevent aspartimide formation, were used to obtain respectively analogs $\mathbf{8 c}$ and 8d. ${ }^{12 \mathrm{c}}$ Moreover by using an excess of aldehyde $\mathbf{6}$ a double addition product $\mathbf{1 0}$ was obtained in $47 \%$ yield in the case of reductive amination of L-glutamic acid derivative $7 \mathbf{c}$ (Figure 1). ${ }^{13}$ Derivatives $\mathbf{1 b}$ and $\mathbf{1 c}$ along with compound $\mathbf{2 b}$ were also synthesized by standard procedures for sake of comparison.

We thought it would be worthwile to test the introduction of a spacer between the Asp and Lys residue of reversin $121 \mathrm{1}$. Thus, we chose to synthesize the protected Asp- $\psi\left(\mathrm{CO}-\mathrm{CH}_{2}\right)$ Gly-Lys ketomethylene analog 16 as outlined in Scheme 3. The synthesis started from L-homoserine which was protected on the side chain as a tert-butyl dimethyl silyl ether followed by protection of the free $\alpha$-amine as tertbutyloxycarbonyl derivative and finally transformed in Weinreb amide 11 in $40 \%$ overall yield over three steps. The alkene 12 was then obtained from Weinreb amide 11 by alkylation with butenyl magnesium bromide as described ${ }^{14}$ in 55\% yield. Transformation of the protected hydroxyl of $\mathbf{1 2}$ in benzyl ester $\mathbf{1 3}$ was carried out by oxidation of the deprotected hydroxyl with PDC and then esterification of the cesium salt in $53 \%$ overall yield as described. ${ }^{15 a, 15 b}$ Oxidation of alkene 13 with $\mathrm{RuCl}_{3} \mathrm{xH}_{2} \mathrm{O} / \mathrm{NaIO}_{4}$ afforded free acid $\mathbf{1 4}$ in $96 \%$ yield. The ketomethylene analog 16 was finally obtained by coupling the succinimidyl derivative $\mathbf{1 5}$ and diprotected L-lysine hydrochloride in 94\% yield. 


\section{References and Notes}

1. Gottesman, M. M.; Fojo, T.; Bates S. E. Nature Rev. Cancer 2002, 2, 48.

2. Gottesman, M. M.; Pastan, I.; Ambudkar, S. V. Curr. Opin. Genet. Dev., 1996, 6, 610.

3. Szakács, G.; Paterson, J. K.; Ludwig, J. A.; BoothGenthe, C.; Gottesman, M. M. Nature Rev. Drug Discovery, 2006, 5, 219.

4. Teodori, E.; Dei, S.; Scapecchi, S.; Gualtieri, F. Il Farmaco, 2002, 57, 385.

5. (a) Sharom, F. J.; DiDiodato, G.; Yu, X.; Ashbourne, K. J. D. J. Biol. Chem. 1995, 270, 10334. (b) Seprödi, J.; Mezõ, I.; Vadász, Zs.; Szabó, K.; Sarkadi, B.; Teplán, I. In Peptides 1996; Proceedings of the $24^{\text {th }}$ European Symposium, 1996, Edimburgh; Ramage, R., Epton, R., Eds; Mayflower Scientific Ltd: Kingswinford, 1998; pp 801-802. (c) Vadász, Zs.; Szabó, K.; Sarkadi, B.; Teplán, I.; Mák, M.; Miklós, I.; Györffy, E.; Seprödi, J. In Peptides 1998; Proceedings of the $25^{\text {th }}$ European Symposium, 1998, Budapest; Bajusz, S., Hudecz, F., Eds; Akademiai Kiado Ed: Budapest, 1999; pp 640-641.

6. Sharom, F. J.; Yu, X.; Lu, P.; Liu, R.; Chu, J. W. K.; Szabó, K.; Müller, M.; Hose, C. D.: Monks, A.; Váradi, A.; E.; Seprödi, J.; Sarkadi, B. Biochem. Pharmacol., 1999, $58,571$.

7. Martinez, J.; Bali, J.-P.; Rodriguez, M.; Castro, B.; Magous, R.; Laur, J.; Lignon, M.-F. J. Med. Chem., 1985, $28,1874$.

8. The aminoaldehydes were synthesized by reduction of aminoacids derived mixed anhydrides with $\mathrm{NaBH}_{4}$ and then oxidized by Swern oxidation.

9. VanRheenen, V.; Kelly, R. C.; Cha, D. Y. Tetrahedron Lett., 1976, 17, 1973.

10. (a) Baldwin, J. E.; Hulme, C.; Edwards, A. J.; Schofield, C. J.; Parkes, K. E. B. Tetrahedron Lett., 1993, 34, 1665. (b) Delcros, J.-G.; Tomasi, S.; Carrington, S.; Martin, B.; Renault, J.; Blagbrough, I. S.; Uriac, P. J. Med. Chem., 2002, 45, 5098. (c) Spectral data of diastereoisomeric hemiaminals 6': IR (film, $v \mathrm{~cm}^{-1}$ ): 3412 $(\mathrm{OH}$ and $\mathrm{NH}), 3066$ (arom $\mathrm{CH}), 2954$ (al CH) , 1738 $(\mathrm{C}=\mathrm{O}$ ester), 1674 ( $\mathrm{CO}$ amide). ESIMS (negative mode, $\mathrm{NaCl}): 856,9\left(2 \mathrm{M}+\mathrm{Cl}^{-}\right), 446,0\left(\mathrm{M}+\mathrm{Cl}^{-}\right) .{ }^{1} \mathrm{H} \mathrm{NMR}(300$ $\left.\mathrm{MHz} \mathrm{CDCl}_{3}, \delta \mathrm{ppm}\right): 7.36(20 \mathrm{H}, \mathrm{m}, 4 \mathrm{Phe}), 5.31(2 \mathrm{H}, \mathrm{m}$, $2 \mathrm{CHOH}), 5.18\left(4 \mathrm{H}, \mathrm{m}, 2 \mathrm{CH}_{2} \mathrm{O} \mathrm{Bn}\right), 5.12(4 \mathrm{H}, \mathrm{m}, 2$ $\left.\mathrm{CH}_{2} \mathrm{O} \mathrm{Bn}\right), 4.77(1 \mathrm{H}, \mathrm{dd}, \mathrm{J}=4.5$ and $9.8 \mathrm{~Hz}, \mathrm{CH} \alpha), 4.64$ $(1 \overline{\mathrm{H}}, \mathrm{t}, \mathrm{J}=7.1 \mathrm{~Hz}, \mathrm{CH} \alpha), 4.32(1 \mathrm{H}, \mathrm{d}, \mathrm{J}=4.5 \mathrm{~Hz}$, exch $\mathrm{OH}), 3.41(1 \mathrm{H}, \mathrm{d}, \mathrm{J}=7.8 \mathrm{~Hz}$, exch $\mathrm{OH}), 1.8-2.8(16 \mathrm{H}, \mathrm{m}$, $2-\underline{\mathrm{C}}_{2} \mathrm{CH}_{2}-$ and $\left.2-\underline{\mathrm{CH}}_{2} \underline{\mathrm{CH}}_{2}-\mathrm{Glu}\right) .{ }^{13} \mathrm{C} \mathrm{NMR}(75 \mathrm{MHz}$, $\left.\mathrm{CDCl}_{3}, \delta \mathrm{ppm}\right): 176.3(\mathrm{C}=\overline{\mathrm{O}}), 175.8(\mathrm{C}=\mathrm{O}), 173.7(\mathrm{C}=\mathrm{O})$, $173.1(\mathrm{C}=\mathrm{O}), 172.8(\mathrm{C}=\mathrm{O}), 171.0(\mathrm{C}=\mathrm{O}), 136.0(\mathrm{Cq} \mathrm{Phe})$, 135.9 (Cq Phe), 135.5 (Cq Phe), 135.2 (Cq Phe), 129.1 (CH Phe), 129.07 (CH Phe), 129.02 (CH Phe), 128.9 (CH Phe), 128.8 (CH Phe), 128.7 (CH Phe), 128.6 (2 CH Phe), $84.4(\mathrm{CHOH}), 82(\mathrm{CHOH}), 68.3\left(\mathrm{CH}_{2} \mathrm{O}\right), 67.9\left(\mathrm{CH}_{2} \mathrm{O}\right)$, $67.1\left(\underline{\mathrm{CH}}_{2} \mathrm{O}\right), 67.0\left(\underline{\mathrm{CH}}_{2} \mathrm{O}\right), 54.7(\underline{\mathrm{CH}} \alpha), 54.3(\underline{\mathrm{CH}} \alpha), 31.3$ $\left(\underline{\mathrm{CH}}_{2}\right), 30.0\left(\underline{\mathrm{CH}}_{2}\right), 29.5\left(\underline{\mathrm{CH}}_{2}\right), 29.3\left(\underline{\mathrm{CH}}_{2}\right), 29.0\left(\underline{\mathrm{CH}}_{2}\right)$, $28.8\left(\underline{\mathrm{CH}}_{2}\right), 25.7\left(\underline{\mathrm{CH}}_{2}\right), 24.6\left(\mathrm{CH}_{2}\right)$.

11. Gareau, Y.; Zamboni, R.; Wong, A.W. J. Org. Chem., 1993, $58,1582$.

12. (a) Karlström, A. H.; Undén, A. E. Tetrahedron Lett., 1995, 36, 3909. (b) Tam, J. P.; Wong, T.-W.; Riemen, M. W.; Tjoeng, F.-S.; Merrifield, R. B. Tetrahedron Lett., 1979, 42, 4033. (c) H-Glu(ODmp)-OBn 7c was synthesized from commercial $N^{a}$ Boc-Glu-OBn by side chain esterification with DCC/DMAP and 2,4-dimethyl-3pentanol in dichloromethane in $70 \%$ yield and then Boc deprotected with conc $\mathrm{H}_{2} \mathrm{SO}_{4}$ in AcOEt in $95 \%$ yield. $\mathrm{H}$ $\mathrm{Glu}(\mathrm{O} c \mathrm{Hex})-\mathrm{OBn}$ 7d was obtained from commercial $N$ Boc-Glu(OcHex)-OH by esterification of the $\alpha$ carboxylic acid with benzyl bromide and cesium carbonate in $\mathrm{MeOH} / \mathrm{H}_{2} \mathrm{O}$ in $70 \%$ yield and then Boc deprotected in the same conditions as previously in $96 \%$ yield.

13. See Salvi, J. P.; Walchshofer, N.; Paris, J. Tetrahedron Lett., 1994, 35, 1181 for similar formation of double condensation product in reductive amination reactions.

14. Kaiser, M.; Siciliano, C.; Assfalg-Machleidt, I.; Groll, M.; Milbradt, A. G.; Moroder, L. Org. Lett., 2003, 5, 3435.

15. (a) Våbenø, J.; Nielsen, U.; Ingebrigtsen, T.; Lejon, T.; Steffansen, B.; Luthman, K. J. Med. Chem., 2004, 47, 4755. (b) As racemisation of a similar benzylated ester was noted in the cited reference $15 \mathrm{a}$ the enantiomeric purity of $\mathbf{1 3}$ was checked and found enantiomerically pure by $\mathrm{C} 18$ RP-HPLC analysis after deprotection (TFA $/ \mathrm{CH}_{2} \mathrm{Cl}_{2}$ ) and derivatisation with GITC.

16. (a) Comte, G.; Daskiewicz, J.-P.; Bayet, C.; Conseil, G.; Viornery-Vanier A.; Dumontet, C.; Di Pietro, A.; Barron, D. J. Med. Chem., 2001, 44, 763. (b) One million K562/R7 human leukemic cells expressing high levels of P-glycoprotein were incubated for 1 hour at $37^{\circ} \mathrm{C}$ in $1 \mathrm{~mL}$ of RPMI 1640 medium containing a final concentration of $10 \mu \mathrm{M}$ daunorubicin, in the presence or absence of inhibitor. The cells were then washed twice with ice-cold phosphate buffer saline (PBSt), and kept on ice until analysis by flow cytometry on a FACS-II. Assays were performed in duplicate, with at least three separate experiments. 